\begin{tabular}{|l|l|l|}
\hline \multicolumn{2}{|c|}{ PublisherInfo } \\
\hline \hline PublisherName & $:$ & BioMed Central \\
\hline \hline PublisherLocation & $:$ & London \\
\hline \hline PublisherImprintName & $:$ & BioMed Central \\
\hline \hline
\end{tabular}

\title{
Repair polymerases in a double act
}

\begin{tabular}{|l|l|l||}
\hline \multicolumn{2}{|c|}{ ArticleInfo } \\
\hline \hline ArticleID & $:$ & 3759 \\
\hline \hline ArticleDOI & $:$ & $10.1186 /$ gb-spotlight-20000906-01 \\
\hline \hline ArticleCitationID & $:$ & spotlight-20000906-01 \\
\hline \hline ArticleSequenceNumber & $:$ & 196 \\
\hline \hline ArticleCategory & $:$ & Research news \\
\hline \hline ArticleFirstPage & $:$ & 1 \\
\hline \hline ArticleLastPage & $:$ & 2 \\
\hline \hline & & RegistrationDate : 2000-09-06 \\
ArticleHistory & $:$ & OnlineDate \\
\hline \hline ArticleCopyright & $:$ & BioMed Central Ltd2000-09-06 \\
\hline \hline ArticleGrants & $:$ & \\
\hline \hline ArticleContext & $:$ & 130591111 \\
\hline \hline
\end{tabular}




\section{William Wells}

Email: wells@biotext.com

In the 31 August Nature Johnson et al. report that two eukaryotic DNA polymerases act sequentially to repair DNA lesions (Nature 2000, 406:1015-1019). DNA polymerase iota is a low fidelity polymerase that is particularly error-prone opposite a normal T residue, but when faced with the extremely distorted (6-4) T-T photoproduct it can successfully incorporate an A. It also does well opposite a noninstructional abasic lesion, but in neither case can it extend beyond the lesion. DNA polymerase $\zeta$ shows the opposite combination of properties. It cannot incorporate nucleotides opposite lesions, despite its known involvement in DNA repair. But it shows high fidelity in extending from the nucleotides inserted opposite DNA lesions by DNA polymerase 1.

\section{References}

1. Nature, [http://www.nature.com/nature/]

2. Novel human and mouse homologs of Saccharomyces cerevisiae DNA polymerase eta. 